\title{
1 Long-lasting floods buffer the thermal regime of the Pampas
}

2 Javier Houspanossian ${ }^{\mathrm{a}, \mathrm{b} *}$, Sylvain Kuppel ${ }^{\mathrm{a}, \mathrm{c}}$, Marcelo Nosetto ${ }^{\mathrm{a}, \mathrm{d}}$, Carlos Di Bella ${ }^{\mathrm{e}, \mathrm{f}}$,

3 Patricio Oricchio ${ }^{\mathrm{e}}$, Mariana Barrucand ${ }^{\mathrm{g}}$, Matilde Rusticucci ${ }^{\mathrm{g}}$, Esteban Jobbágy ${ }^{\mathrm{a}}$

4 Affiliation: ${ }^{\mathrm{a}}$ CONICET, San Luis, Argentina. ${ }^{\mathrm{b}}$ Facultad de Ciencias Físico Matemáticas y

5 Naturales, Universidad Nacional de San Luis, San Luis, Argentina. ${ }^{\mathrm{c}}$ Northern Rivers

6 Institute, School of Geosciences, University of Aberdeen, United Kingdom. ${ }^{\mathrm{d}}$ Cátedra de

7 Climatología Agrícola, Facultad de Ciencias Agropecuarias, Universidad Nacional de Entre

8 Ríos, Oro Verde, Argentina. ${ }^{\mathrm{e}}$ INTA - Instituto de Clima y Agua, Argentina. ${ }^{\mathrm{f}}$

9 Departamento de Métodos Cuantitativos, Facultad de Agronomía, Universidad de Buenos

10 Aires \& CONICET, Argentina. ${ }^{\mathrm{g}}$ Departamento de Ciencias de la Atmósfera y los Océanos,

11 Facultad de Ciencias Exactas y Naturales, Universidad de Buenos Aires \& CONICET,

12 Argentina

13 * Corresponding author: jhouspa@gmail.com, Tel: +54-266-4424740 - Fax +54-266-

$14 \quad 4422803$ 


\section{Abstract}

The presence of large water masses influences the thermal regime of nearby land shaping the local climate of coastal areas by the ocean or large continental lakes. Large surface water bodies have an ephemeral nature in the vast sedimentary plains of the Pampas (Argentina) where non-flooded periods alternate with flooding cycles covering up to one third of the landscape for several months. Based on temperature records from 17 sites located 1 to $700 \mathrm{~km}$ away from the Atlantic coast and MODIS land surface temperature data, we explore the effects of floods on diurnal and seasonal thermal ranges as well as temperature extremes. In non-flooded periods there is a linear increase of mean diurnal thermal range (DTR) from the coast towards the interior of the region (DTR increasing from 10 to $16 \mathrm{~K}, 0.79 \mathrm{~K} / 100 \mathrm{~km}, \mathrm{r}^{2}=0.81$ ). This relationship weakens during flood episodes when the DTR of flood-prone inland locations shows a decline of 2 to $4 \mathrm{~K}$, depending on surface water coverage in the surrounding area. DTR even approaches typical coastal values $500 \mathrm{~km}$ away from the ocean in the most flooded location that we studied during the three flooding cycles recorded in the study period. Frosts-free periods, a key driver of the phenology of both natural and cultivated ecosystems, are extended by up to 55 days during floods, most likely as a result of enhanced ground heat storage across the landscape $(\sim 2.7$ fold change in day-night heat transfer) combined with other effects on the surface energy balance such as greater night evaporation rates. The reduced thermal range and longer frostfree periods affect plant growth development and may offer an opportunity for longer crop growing periods, which may not only contribute to partially compensating for regional production losses caused by floods, but also open avenues for flood mitigation through higher plant evapotranspirative water losses. 


\section{Introduction}

Many geographical and environmental factors combine to influence the thermal regimes across Earth's continental surface. Some of the most prominent ones are latitude, altitude, large-scale atmospheric circulation patterns, and proximity to the large water bodies, often altogether merged in the concept of continentality (Ninyerola et al. 2000). While the first three factors have a dominant influence on mean temperatures, the proximity to large surface water including oceans and large lakes primarily affects the range of diurnal (i.e. between day and night) and seasonal (i.e. between cold and warm seasons) temperature cycles (Ninyerola et al. 2000; Scott and Huff 1996). Compared to land, surface water have a larger thermal inertia, and as a result coastal areas have more moderate temperature extremes than those located inland (Ninyerola et al. 2000). While classical studies have explored how the proximity to the ocean (Aschmann 1973) or very large lakes (Kopec 1967; Scott and Huff 1996) shapes terrestrial thermal regimes, little is known about how the latter are affected by widespread but ephemeral surface water bodies that cover many flood-prone regions of the world. To what extent can this temporary surface water recreate the coastal effects of large lakes or the ocean in the interior of continents? What are the specificities associated with their transient nature? How can this influence the plant growth development in the region? These are important questions that need to be answered in order to better understand the reciprocal effect of floods on local-to-regional climate.

Surface water can shape the thermal regime of the surrounding landscape through multiple mechanisms. First, as their depth increase they can store and transfer heat not only at the daily scale but also at weekly to seasonal scales (Eaton et al. 2001; Nordbo et al. 2011;

Oncley et al. 1997; Rouse et al. 2005), buffering thermal fluctuations and thus the magnitude 
65 of temperature extremes in the adjacent land through advective exchange (Hinkel and Nelson 66 2012; Nicholls and Toumi 2014). In addition to this advective feedback, shallow surface 67 water bodies can transfer latent heat as evaporation supplies vapor that condensates above 68 nearby land (Higgins et al. 2013; Wang et al. 2014). More complex microclimatic mechanisms may also take place, including the development of low fog banks that prevent nocturnal longwave radiation losses or the development of local breezes (Geiger 1967; Hinkel and Nelson 2012). The magnitude and spatial extension of the effects of surface water on inland territory are determined by wind patterns, roughness factors (e.g., orography and land cover), and the magnitude of contrasts in thermal regimes between land and water (Kopec 1967). The complexity of local and remote atmospheric effects that surface water bodies can exert has been illustrated by modeling studies (Krinner 2003; Long et al. 2007; Mallard et al. 2015; Samuelsson et al. 2010; Subin et al. 2012). Yet, direct empirical observations describing how vast but ephemeral inland surface water influence temperatures in the land are still missing in the literature. This is probably because most large inland surface water are either permanent lakes, whose effect can only be captured through "static" spatial comparisons, and more generally because the impact of seasonal surface water has not been disentangled from background thermal variability. $\mathrm{km}^{2}$, that experiences large episodic flood events covering a significant fraction of the landscape for months or even years (Aragón et al. 2011; Kuppel et al. 2015; Moncaut 1978; Moncaut 2001). This particular orographic/climatic setting is shared by several regions around the world, including the Pantanal (Brazil) (Hamilton et al. 2002), the Orinoco Llanos (Colombia and Venezuela) (Hamilton et al. 2004), the plains of Manitoba and Saskatchewan 
(Canada) (Jobbágy et al. 2008), the Great Plains of Hungary (Jobbágy et al. 2008), and Western Siberia (Biancamaria et al. 2009). In particular, the widespread but ephemeral presence of surface water in the Pampas and the dominance of a year-to-year variability rather than regular seasonal cycles - in contrast to the Amazon and other large riverdominated floodplains- make this region highly relevant for the empirical exploration of thermal effects of floods through space and time.

In flooded landscapes, temperature extremes are buffered under otherwise similar mean temperature conditions, and heat accumulation rates and the occurrence of frosts may change, affecting plant growth and phenology. Given that the Pampas are mostly covered by annual crops that have displaced cultivated pastures and native grasslands (Baldi and Paruelo 2008; Hall et al. 1992; Viglizzo et al. 2009), its agricultural production including crop choice and farming practices are particularly sensitive to seasonal and diurnal thermal fluctuations. A better knowledge of the consequences of floods for air temperature variability, and on the occurrence of frost in particular, is thus critical for optimizing agronomic management $(\mathrm{Gu}$ et al. 2008) in this region whose economy heavily relies on the productivity of agricultural ecosystems.

In this study we present empirical evidence of the effects that widespread and longlasting floods have on the thermal regime of the Pampas. We focus on diurnal and seasonal thermal range as general indicators of thermal buffering by surface water and on frost occurrence, the latter being considered as a variable of key agronomic relevance (Andrade and Satorre 2015; Madonni 2012). We assess flooding extent based on satellite imagery and analyze temperature data retrieved from both ground meteorological stations and remote sensing instruments. We combine 1) a spatial analysis along a $700 \mathrm{~km}$-long transect from the 
111

112

113

114

115

116

117

118

119

120

121

122

123

124

125

126

127

128

129

130

131

132

133

Atlantic coast to the western edge of the Pampas across a major cycle of long-term flooded and the subsequent non-flooded periods (2000-2003 vs. 2004-2009, respectively) with 2) a longer term analysis of three locations (coastal without floods, inland with floods, inland without floods) covering four decades and encompassing three major flooding episodes.

\section{Study area}

In the Pampas of Argentina (Fig. 1) the climate ranges from humid in northeast grading to sub-humid towards the southwest, with mean annual precipitation decreasing from 1200 to $600 \mathrm{~mm} /$ year (1960-2010, Magliano et al. 2015). Mean annual temperature ranges from $18{ }^{\circ} \mathrm{C}$ to $14{ }^{\circ} \mathrm{C}$ along a N-S gradient. As in the entire temperate belt of the Southern Hemisphere, winter-summer temperature contrasts in the study region are generally smaller than those observed in most comparable temperate latitudes of the Northern Hemisphere (respectively $<20{ }^{\circ} \mathrm{C}$ and $>30^{\circ} \mathrm{C}$ difference between the mean temperature of the warmest and coldest month) (Jobbágy and Jackson 2000). The region encompasses eolian and alluvial sedimentary landscapes that were shaped during the last glaciations (Iriondo 1999). Extremely low regional slopes $(<0.1 \%)$ result in poor drainage and widespread shallow water tables, which, combined with a close-to-zero water balance, favors the episodic development of long-lasting floods that develop and retreat over several years accompanying periods of exceptionally high rainfall (Aragón et al. 2011). Originally covered by native grasslands (Soriano 1992), the Pampas were subject to extensive cattle grazing until the beginning of the twentieth century when the onset of cultivation took place. Since that time the rotation of rainfed annual crops with pastures has been widespread, followed in the last two decades by the expansion of summer crops over pastures with a predominance of soybean, which is in some locations preceded by wheat in a double cropping scheme. 


\section{Materials and methods}

The response of the thermal regime to flooding was explored following two complementary approaches. We first conducted a spatial analysis using data from 17 field meteorological stations from Argentina National Weather Service and National Agricultural Technology Institute, located along a gradient of increasing distance from the Atlantic Ocean (1 to $700 \mathrm{~km}$ ) (Fig. 1). In this analysis, we considered a relatively brief period of time for which full in situ daily data was fully available (2000-2013), which includes years with high variability in rainfall, being very wet years (PPT anomaly, 200-400 mm higher than the average 2000-2003, 2012) and very dry (400 mm below average, 2009) (Kuppel et al. 2015). Flooding was mapped based on MODIS albedo data after calibration with LANDSAT imagery, following Kuppel et al. (2015). For each location, we obtained values of mean and maximum flooded area fraction considering surrounding areas of $10 \mathrm{~km}$-radius and grouped them according to the maximum fraction of flooded area (nil/low $<5 \%$, intermediate $5-20 \%$, high $>20 \%$ ). We combined this information with remotely sensed land surface temperature (LST) from the MODIS instrument (MOD11A2 V005 product), downloaded from NASA's Earth Observing System (http://reverb.echo.nasa.gov/reverb), which provides day and night LST values every 8 days at $1 \times 1 \mathrm{~km}$ spatial resolution, based on two diurnal temperature records at $\sim$ 03:00 and $\sim 15: 00$ hours (UTC time). In this case the surface temperature is retrieved using the generalized split-window algorithm with two thermal bands with a reported accuracy of $1 \mathrm{~K}$ (Wang et al. 2008).

The second approach was to analyze the temporal variability of air temperatures at three stations, taken as representative of coastal non-flooded (Mar del Plata), inland flooded (Pehuajó) and inland non-flooded (Anguil) locations (Fig. 1). In this case the analysis 
157

158

159

160

161

162

163

164

165

166

167

168

169

170

171

172

173

174

175

176

177

178

179

encompassed 42 years of climatic data (1971-2013), and 33 years of surface water observations for the flooded station (1980-2013). We applied 365-day moving averages to the diurnal thermal range in order to filter out synoptic and seasonal variability and capture interannual climatic effects. We also computed latest/earliest frosts and the frost-free period each year. We defined freezing conditions as air temperatures of $<2{ }^{\circ} \mathrm{C}$ at the meteorological station $\left(1.5 \mathrm{~m}\right.$ above the ground) which typically corresponds with freezing $\left(0^{\circ} \mathrm{C}\right)$ at the ground surface (Hirshhorn 1952). Flooding records included estimates based on LANDSAT (1980-2000) and MODIS (2000-2013) imagery, again following the methodology described in Kuppel et al. (2015) and in Ballesteros (2014). Before 1980 we used qualitative flood records in local newspaper archives, completed by an existing historical synthesis of extreme wet/dry events in the region (Moncaut 1978; Moncaut 2001).

In order to understand the physical mechanisms behind the patterns presented here, we estimated the theoretical diurnal heat exchange of landscapes during flooded a and nonflooded periods. Heat storage/release estimates are presented for five possible levels stages of the territory: dry soil (50:50\% air-particles), humid soil (field capacity, 15:50\%), waterlogged soil (saturation, 0:50\%), flooded land (0-50 cm water column) and permanent water ( $>1 \mathrm{~m}$ of water column). For each situation the amount of heat exchanged daily was estimated based on the product of the range and depth of thermal cycle and the heat capacity of the engaged volume, which was calculated considering the heat capacity of water, air and soil particles and their mass contribution to that volume. Water contents are those typically observed in the loamy soils of the region and heat capacity values of soil particles and water are 0.8 and $4.22 \mathrm{KJ} /(\mathrm{Kg} \mathrm{K})$ and bulk density and porosity assumed to be 1.3 and $0.5 \mathrm{Mg} / \mathrm{m}^{3}$, respectively. Values are scaled at the landscape level considering the area fraction of each 
180

181

182

183

184

185

186

187

188

189

190

191

192

193

194

195

196

197

198

199

200

201

situation in non-flooded vs. flooded periods. Thermal wave range and depth for soils were obtained from Hillel (2003) and from unpublished field observations in deep and shallow lagoons of the Pampas (Dr. Horacio Zagarese, personal communication). An important aspect of the shallow surface water bodies is that they rarely exceed $50 \mathrm{~cm}$ of depth as shown by a previous volumetric analysis (Aragón et al. 2011).

\section{Results}

Over the Pampas, the air temperature diurnal thermal range (DTR, difference between maximum and minimum daily temperature) increased when moving inland from the ocean coast (Fig. 2a, $\mathrm{p}<0.05$ ) whereas no significant relationship was found at the seasonal scale (Fig. 2b, $\mathrm{p}>0.05)$. Decadal meteorological records (2000-2013) showed that while the coastal stations had a mean DTR of $\sim 10 \mathrm{~K}$, this value raised to $\sim 16 \mathrm{~K}$ in the most continental station $(0.79 \mathrm{~K} / 100 \mathrm{~km}$, Fig. 2a). Further, this diurnal gradient was more pronounced in the cold (April to September) than in the warm (October to March) season with mean gradients of 1.14 vs. $0.61 \mathrm{~K}$ for every $100 \mathrm{~km}$ of distance away from the coast $\left(\mathrm{r}^{2}=0.86\right.$ and 0.71 , respectively, data not shown). When the cold season DTR of the last long-lasting flooded period (2000-2003) was compared with that of the following non-flooded period (2004-2009) thermal changes appeared to be affected by the degree of flooding shown by each station

(Fig. 2c). While the overall cold season DTR gradient showed a slight decline during the three year-long flood (mean DTR $=13.11$ and 11.56, for flooded and non-flooded periods, respectively), highly flooded stations showed a much higher decline in their DTR compared to the rest of the stations (Fig. 2c). This last result was confirmed by grouping stations according to the percentage of flooded area, as we found a DTR decline of about $3 \mathrm{~K}(+1.18 \mathrm{~K}$ 
202

203

204

205

206

207

208

209

210

211

212

213

214

215

216

217

218

219

220

221

222

223

224

and $-1.9 \mathrm{~K}$ change in minimum and maximum temperature, respectively) in the most flooded stations as compared to about $1 \mathrm{~K}$ for nil/low flooded stations (Table 1).

Remote sensing observations of diurnal thermal range based on land surface temperature from night and day hours (LST-DTR) during the cold season (April to September) confirmed the prevailing east-west regional DTR gradient captured with meteorological records (Fig. 3a and b). Flooded areas displayed exceptionally low LST-DTR values, even lower than the coastal ones, during the flooded period (Fig. 3a). During the nonflooded period, this continental "island" of low thermal range shrank and LST-DTR regionally increased, but the latter remained lower than typical continental values next to the perennial surface water of the region (Fig. 3b). Lastly, a detailed analysis of an area of 23,000 $\mathrm{km}^{2}$ conducted around the town of Pehuajó comparing flooded (2000-2003) and non-flooded (2004-2009) periods showed that LST-DTR respectively shifted from $4.7 \pm 1.8 \mathrm{~K}$ to $12.7 \pm 2.0$ $\mathrm{K}$ in the ephemerally flooded areas. However, it also displayed an important difference in the non-flooded fraction of the landscape where LST-DTR significantly changed from $10.4 \pm 1.1$ $\mathrm{K}$ to $15.2 \pm 1 \mathrm{~K}$, respectively (Fig. 3c). This result highlights the thermal effect of surface water beyond their own geographical limits, at least several kilometers into the nearby land.

The long-term analysis shows how inland floods decreased the diurnal thermal range towards those levels observed close to the ocean (Fig. 4). During flood years, DTR at the flood-prone inland location of Pehuajó approached the values typically observed in the coastal non-flooded location of Mar del Plata $(<12 \mathrm{~K})$, while remaining closer to the higher levels $(>12 \mathrm{~K})$ recorded in the inland non-flooded location of Anguil during the rest of the time (Fig. 4a and c). The anomaly of DTR in Pehuajó, computed as the difference between the mean of a given month and the all-time monthly mean (i.e. the mean seasonal cycle), 
225 followed flooding levels, something that become particularly evident when the moving 226 average of 12 months was considered (Fig. 4b and c). Periods of low DTR occurred during 227 the last three intense floods of 1986-1988, 1998-2003, and the relative brief one recorded in 228 2012, as revealed by remote sensing estimates of flooded area (Kuppel et al. 2015). The mild 229 flood of 1991-1993 appeared to have little effect on DTR. Also, a brief period of low DTR 230 was detected in 1973, before remote sensing records of flooding were available, but 231 coincidently with records of flood damages in local newspapers (Fig. 4). the flooded area, with an average decline close to $1.5 \mathrm{~K}$ per $10 \%$ of increasing surface water 234 cover (Fig. 5). This association become tighter at the annual scale $\left(r^{2}=0.71\right.$ for mean annual 235

DTR vs. mean annual flooded area, $\mathrm{p}<0.05$, data not shown), while rainfall displayed a poorer association $\left(\mathrm{r}^{2}=0.36\right.$ for mean annual DTR vs. annual rainfall, $\mathrm{p}<0.01$, data not shown). Very rainy years may have decreased DTR levels in the whole region, as suggested by the low general values observed during 2001 which was one of the three wettest years of the series, yet DTR at Pehuajó also remained close to the low values of Mar del Plata in less rainy but still flooded years like 2002 (Fig. 4).

Flooding also modified the dates of occurrence of early-season and late-season frost, 242 increasing the length of the frost-free period in the flood-prone site of Pehuajó during the 243 flooded period compared to the non-flooded one $(\mathrm{p}<0.05)$ (Fig. 6). By contrast, no significant 244 changes were registered for the same periods at the non-flooded site of Anguil or at the 245 coastal site of Mar del Plata. Accordingly, the frost-free period expanded by 55 days $(\mathrm{p}<0.01)$ 246 in Pehuajó during the flooding period, but by less than 5 days (non-significant change) in the 247 other sites. 
While the effects of flooding on cold temperatures were very clear, we found no 249 significant effects on high summer temperatures. At Pehuajó we looked for the number of 250 days per year with maximum temperatures above 30 and $35^{\circ} \mathrm{C}$, finding no differences in the

251 first case and a slight but non-significant decrease in the second case (7.6 \pm 6.4 vs. $3.6 \pm 4.2$ 252 days/year in flooded vs. non flooded periods). third of inland landscapes) overlap with the thermal effects of ocean proximity, with both 256 buffering variability in air and surface temperatures and reducing the diurnal thermal range. 257 This temporary effect of floods resembles the permanent one described for territories 258 adjacent to large surface water as in the classical studies around the Great Lakes in the United 259 States (Hinkel and Nelson 2012; Kopec 1967) and, more recently, in the wetlands of Sanjiang 260 in China (Liao et al. 2013). However, our case provides a new setting that allows the 261 empirical distinction between spatial and temporal effect. Further, the effect of floods on the 262 local thermal regime appears to be direct and not mediated by feedbacks on rainfall patterns. 263 Indeed, an in-depth analysis in the area surrounding the most flooded station of Pehuajó 264 showed that DTR values displayed a stronger association with flooding than precipitation.

Although the specific mechanisms by which the presence of surface water influences 266 air and surface temperature patterns over the land are not explored in this study, we can infer 267 that the enhanced ground heat storage across the landscape during flooding periods $(\sim 2.7$ fold 268 in flooded vs. non-flooded conditions, Table 2), together with other direct effects on the 269 surface energy balance (i.e. the greater evapotranspiration from surface water) can explain 
270 the observed thermal buffering of air masses above shallow surface waters (Hinkel and 271 Nelson 2012). Indeed, enhanced heat accumulation in water during the day in flooded areas 272 (as compared to an non-flooded landscape) is likely to stimulate latent heat losses during the 273 night, as shown for shallow lakes in China where high night-time evaporation has been 274 recorded (Wang et al. 2014). Conversely, sensible heat losses during the night may be less 275 important in flooded locations given the comparatively low roughness of water. Besides, 276 local advection can transfer heat laterally away from the surface of water into the adjacent 277 non-flooded zones where it could be released through night-time condensation (Hinkel and 278 Nelson 2012; Liao et al. 2013; Wang et al. 2014), explaining the anomalous thermal patterns 279 away from the heat source, as recently found in rice fields of California (Baldocchi et al. 280 2016). Lastly, more complex local-scale meteorological processes such as local breezes and 281 fog formation may contribute to the observed thermal buffering (Geiger 1967; Kopec 1967; 282 Scott and Huff 1996). Another key aspect to understand how the thermal effect of surface water relates to 284 the landscape configuration in the flooded territory (Baldocchi et al. 2016). Indeed, the 285 importance of local advection between surface water and land may vary according to the 286 depth, size, number and distribution of surface water bodies (Venäläinen et al. 1999) become 287 higher if the same fraction of water coverage is distributed across a large number of small 288 lakes, enhancing edge effects. This is the case of the Pampas where although the typical water 289 depths in the flooded land of Pampas are shallow $(<0.5 \mathrm{~m})$ and the thermal inertial expected 290 is lower in comparison permanent lagoons or marine coasts (Table 2), the aeolian 291 geomorphology has produced a dense mosaic of isolated lowlands occupied by small lagoons 292 and wetlands during floods, within a matrix of higher non-flooded land. We calculated that 
the mean Euclidean distance of any non-flooded inland point to a flooded point was $2.1 \mathrm{~km}$ (Fig. 3c) during maximum flooding, a very short distance when compared to the characteristic length of the effect of surface water over land documented for the Great Lakes (> 25km) (Kopec 1967; Scott and Huff 1996; Subin et al. 2012), but similar to that documented for the wetlands in China $(<2 \mathrm{~km})$ (Liao et al. 2013). It is important to acknowledge that other environmental and microclimatic factors (wind direction and velocity, surface roughness, surface and depth of water, among others) may play a role (Kopec 1967; Liao et al. 2013; Rouse et al. 2005), so that a spatially distributed climate monitoring network would be necessary for a more accurate and mechanistic understanding of the thermal influence of ephemeral surface water in the region.

Thermal changes induced by flooding may affect agricultural and cattle production in different ways. The extension of the growing season of crops during flooding periods can partially offset production losses triggered by the decrease of the cultivated area, which can reach up to 30\% regionally (Aragón et al. 2011; Kuppel et al. 2015). Early-season and lateseason frosts are a strong constraint for crop production in the region. The last frosts in the spring risk the establishment of summer crops that are sown too early and decrease the grain yield of winter crops flowering at that time. Early-season frosts in the fall can reducethe yields of summer crops (Andrade and Satorre 2015; Madonni 2012). Overall, the length of the frost-free window limits to the choice of growing cycles and/or double cropping schemes. The anticipation of a later the late-season frost date during flooding periods (Fig. 6) may allow earlier-sowing of both summer and winter crops, favoring longer growing seasons and higher grain yields (Otegui et al. 1995). On the other hand, delayed early-season frosts can allow later sowing of summer crops favoring the inclusion of a winter crop (e.g. wheat) 
316 before them. Interestingly, these management options could also contribute to mitigate floods

317 by increasing evapotranspirative water losses, which can be increased by up to $25 \%$ if double

318 cropping is implemented (Nosetto et al. 2012). We found an insignificant buffering of 319 maximum summer temperatures by floods, which suggests that thermal buffering does not 320 mitigate heat stress to livestock (West 2003) and grain production systems (Ordóñez et al. $3212015)$. Understanding the local-scale meteorological changes associated with long lasting floods also bears on a critical human health issues. The proliferation of disease vectors such as flies, mosquitoes, and grasshoppers may increase during these periods given the presence 325 of surface water for larvae proliferation as well as the lower thermal fluctuation and the 326 extended frost free period, which usually defines the season of high epidemiological risk for insect-borne diseases (Tabachnick 2010; Thomas et al. 2012).

\section{Conclusions}

We have shown that flooding episodes in the Pampas have a strong influence on the thermal regime of inland areas, reducing diurnal thermal fluctuations to levels that were even lower than those found in coastal locations. Given the low seasonal thermal range of southern

333 South America ( $\sim 14 \mathrm{~K}$ in our study region), the diurnal thermal range ( $\sim 10$ to $16 \mathrm{~K}$ in our 334 study region) has a very strong influence on physical and ecological processes. In addition to 335 the reduction of diurnal thermal variability by floods ( $\sim 3 \mathrm{~K}$ in the most flooded locations), 336 flooding reduced the incidence of frosts and the length of the frost-free period by almost two 337 months. These thermal shifts open an opportunity for longer crop growing periods which not 
338 only may help to compensate regional production losses caused by floods but also may 339 provide an opportunity to mitigate them through higher plant water consumption losses by 340 evapotranspiration.

\section{Acknowledgements}

343 This work was funded by grants from the National Research Council of Argentina

344 (CONICET), the International Research Development Centre [IDRC-Canada, Project

345 106601-001], ANPCyT [PRH 27 [PICT 2013-2973; PICT 2014-2790] and the Inter-

346 American Institute for Global Change Research [IAI, CRN II 2031], which is supported by

347 the US National Science Foundation[Grant number 448 GEO-0452325]. We thank Dr.

348 Horacio Zagarese from INTECH for the lagoon temperature dataset provided. We thank the

349 anonymous reviewers for their careful reading of our manuscript and their many insightful 350 comments and suggestions. 


\section{References}

354 Andrade JF, Satorre EH (2015) Single and double crop systems in the Argentine Pampas:

355 Environmental determinants of annual grain yield Field Crop Res 177:137-147

356 doi:http://dx.doi.org/10.1016/j.fcr.2015.03.008

357 Aragón R, Jobbágy EG, Viglizzo EF (2011) Surface and groundwater dynamics in the sedimentary

358 plains of the Western Pampas (Argentina) Ecohydrology 4:433-447 doi:10.1002/eco.149

359 Aschmann H (1973) Distribution and peculiarity of Mediterranean ecosystems. In: di Castri F, 360 Mooney HA (eds) Mediterranean type ecosystems, vol 7. vol Ecological Studies Springer, Berlin, 361 Heidelberg, pp 11-19

362

363

364

365

366

367

368

369

370

371

372

373

374

375

376

377

378

379

380

381

382

383

384

385

386

387
Baldi G, Paruelo JM (2008) Land use and land cover dynamics in South American temperate grasslands Ecology and Society 13:6

Baldocchi D et al. (2016) The impact of expanding flooded land area on the annual evaporation of rice Agricultural and Forest Meteorology 223:181-193

doi:http://dx.doi.org/10.1016/j.agrformet.2016.04.001

Ballesteros SI (2014) Inundaciones y su relación con el clima y la hidrología subterránea en el Noroeste de Buenos Aires (1980-2010): Aplicación de percepción remota. Universidad de Buenos Aires

Biancamaria S, Bates P, Boone A, Mognard N (2009) Large-scale coupled hydrologic and hydraulic modelling of the $\mathrm{Ob}$ river in Siberia Journal of Hydrology 379:136-150

doi:10.1016/j.jhydrol.2009.09.054

Eaton AK, Rouse WR, Lafleur PM, Marsh P, Blanken PD (2001) Surface energy balance of the Western and Central Canadian Subarctic: Variations in the energy balance among five major terrain types Journal of Climate 14:3692-3703

Geiger R (1967) The climate near the ground Quarterly Journal of the Royal Meteorological Society 93:150-151 doi:10.1002/qj.49709339529

Gu L et al. (2008) The 2007 Eastern US spring freeze: Increased cold damage in a warming world? BioScience 58:253-262

Hall AJ, Rebella CM, Ghersa C, Culot J (1992) Field crop systems of the Pampas. In: Pearson CJ (ed) Ecosystems of the World, Field Crop Ecosystems. Elsevier, Amsterdam, pp 413-450

Hamilton SK, Sippel SJ, Melack JM (2002) Comparison of inundation patterns among major South American floodplains Journal of Geophysical Research: Atmospheres 107:LBA 5-1-LBA 5-14 doi:10.1029/2000jd000306

Hamilton SK, Sippel SJ, Melack JM (2004) Seasonal inundation patterns in two large savanna floodplains of South America: the Llanos de Moxos (Bolivia) and the Llanos del Orinoco (Venezuela and Colombia) Hydrological Processes 18:2103-2116 doi:10.1002/hyp.5559 
Higgins CW, Pardyjak E, Froidevaux M, Simeonov V, Parlange MB (2013) Measured and estimated water vapor advection in the atmospheric surface layer Journal of Hydrometeorology 14:1966-1972 doi:doi:10.1175/JHM-D-12-0166.1

Hillel D (2003) Soil physics and soil physical characteristics. In: Introduction to Environmental Soil Physics (First). Academic Press, Burlington, pp 3-17. doi:http://dx.doi.org/10.1016/B978$\underline{012348655-4 / 50002-2}$

Hinkel KM, Nelson FE (2012) Spatial and temporal aspects of the lake effect on the southern shore of Lake Superior Theoretical and Applied Climatology 109:415-428 doi:10.1007/s00704-012-05852

Hirshhorn J (1952) Las heladas en la República Argentina. Índices Agroclimáticos. Servicio Meteorológico Nacional, Buenos Aires

Iriondo MH (1999) The Neogene of the Llanos-Chaco-Pampa Depression Episodes 22:226-231

Jobbágy EG, Jackson RB (2000) Global controls of forest line elevation in the northern and southern hemispheres Global Ecology and Biogeography 9:253-268 doi:10.1046/j.13652699.2000.00162.x

Jobbágy EG, Nosetto MD, Santoni C, Baldi G (2008) El desafío ecohidrológico de las transiciones entre sistemas leñosos y herbáceos en la llanura Chaco-Pampeana Ecología Austral 18:305-322

Kopec RJ (1967) Effects of the Great Lakes' thermal influence on freeze-free dates in spring and fall as determined by Hopkins' bioclimatic law Agricultural Meteorology 4:241-253

Krinner G (2003) Impact of lakes and wetlands on boreal climate Journal of Geophysical Research: Atmospheres 108:4520 doi:10.1029/2002jd002597

Kuppel S, Houspanossian J, Nosetto M, Jobbágy E (2015) What does it take to flood the Pampas?: Lessons from a decade of strong hydrological fluctuations Water Resources Research 51:2937-2950

Liao X, Liu Z, Wang Y, Jin J (2013) Spatiotemporal variation in the microclimatic edge effect between wetland and farmland Journal of Geophysical Research Atmospheres 118:7640-7650 doi:10.1002/jgrd.50573

Long Z, Perrie W, Gyakum J, Caya D, Laprise R (2007) Northern lake impacts on local seasonal climate Journal of Hydrometeorology 8:881-896 doi:doi:10.1175/JHM591.1

Madonni GA (2012) Analysis of the climatic constraints to maize production in the current agricultural region of Argentina-a probabilistic approach Theoretical and Applied Climatology $107: 325-345$

Magliano PN, Fernández RJ, Mercau JL, Jobbágy EG (2015) Precipitation event distribution in central argentina: Spatial and temporal patterns Ecohydrology 8:94-104 doi:10.1002/eco.1491 
421

422

423

424

425

426

427

428

429

430

431

432

433

434

435

436

437

438

439

440

441

442

443

444

445

446

447

448

449

450

451

452

453

454

455

Mallard MS et al. (2015) Technical challenges and solutions in representing lakes when using WRF in downscaling applications Geoscientific Model Development 8:1085-1096 doi:10.5194/gmd-81085-2015

Moncaut CA (1978) Pampas y Estancias. El Aljibe, City Bell, Bs. As., Argentina

Moncaut CA (2001) Inundaciones y sequías en la pampa bonaerense vol 1-108. El Aljibe, City Bell, Bs.As., Argentina

Nicholls JF, Toumi R (2014) On the lake effects of the Caspian Sea Quarterly Journal of the Royal Meteorological Society 140:1399-1408 doi:10.1002/qj.2222

Ninyerola M, Pons X, Roure JM (2000) A methodological approach of climatological modelling of air temperature and precipitation through GIS techniques International Journal of Climatology 20:1823-1841 doi:10.1002/1097-0088(20001130)20:14<1823::aid-joc566>3.0.co;2-b

Nordbo A, Launiainen S, Mammarella I, Leppäranta M, Huotari J, Ojala A, Vesala T (2011) Longterm energy flux measurements and energy balance over a small boreal lake using eddy covariance technique Journal of Geophysical Research: Atmospheres 116:2119 doi:10.1029/2010jd014542

Nosetto MD, Jobbágy EG, Brizuela AB, Jackson RB (2012) The hydrologic consequences of land cover change in central Argentina Agriculture, Ecosystems and Environment 154:2-11

Oncley SP, Lenschow DH, Campos TL, Davis KJ, Mann J (1997) Regional-scale surface flux observations across the boreal forest during BOREAS Journal of Geophysical Research:

Atmospheres 102:29147-29154 doi:10.1029/97jd00242

Ordóñez RA, Savin R, Cossani CM, Slafer GA (2015) Yield response to heat stress as affected by nitrogen availability in maize Field Crop Res 183:184-203

doi:http://dx.doi.org/10.1016/j.fcr.2015.07.010

Otegui ME, Nicolini MG, Ruiz RA, Dodds PA (1995) Sowing date effects on grain yield components for different maize genotypes Agro J 87:29-33

Rouse WR et al. (2005) The role of northern lakes in a regional energy balance Journal of Hydrometeorology 6:291-305 doi:10.1175/jhm421.1

Samuelsson P, Kourzeneva E, Mironov D (2010) The impact of lakes on the European climate as stimulated by a regional climate model Boreal environment research 15:113-119

Scott RW, Huff FA (1996) Impacts of the Great Lakes on regional climate conditions Journal of Great Lakes Research 22:845-863

Soriano A (1992) Rio de la Plata grasslands Natural grasslands:367-407

Subin ZM, Murphy LN, Li F, Bonfils C, Riley WJ (2012) Boreal lakes moderate seasonal and diurnal temperature variation and perturb atmospheric circulation: Analyses in the Community Earth System Model 1 (CESM1) Tellus, Series A: Dynamic Meteorology and Oceanography 64:121 doi:10.3402/tellusa.v64i0.15639 
456

457

458

459

460

461

462

463

464

465

466

467

468

469

470

471

472

473

474

475

476

477

478

479

480

481

482

483

484

Tabachnick WJ (2010) Challenges in predicting climate and environmental effects on vector-borne disease episystems in a changing world Journal of Experimental Biology 213:946-954 doi:10.1242/jeb.037564

Thomas SM, Obermayr U, Fischer D, Kreyling J, Beierkuhnlein C (2012) Low-temperature threshold for egg survival of a post-diapause and non-diapause European aedine strain, Aedes albopictus (Diptera: Culicidae) Parasites \& Vectors 5:1-7 doi:10.1186/1756-3305-5-100

Venäläinen A, Frech M, Heikinheimo M, Grelle A (1999) Comparison of latent and sensible heat fluxes over boreal lakes with concurrent fluxes over a forest: Implications for regional averaging Agricultural and Forest Meteorology 98-99:535-546 doi:10.1016/s0168-1923(99)00100-8

Viglizzo EF, Jobbágy EG, Carreño LV, Frank FC, Aragón RM, De Oro L, Salvador VS (2009) The dynamics of cultivation and floods in arable lands of central Argentina Hydrology and Earth System Sciences 13:491-502

Wang W, Liang S, Meyers T (2008) Validating MODIS land surface temperature products using long-term nighttime ground measurements Remote Sensing of Environment 112:623-635 doi:http://dx.doi.org/10.1016/j.rse.2007.05.024

Wang W et al. (2014) Temporal and spatial variations in radiation and energy balance across a large freshwater lake in China Journal of Hydrology 511:811-824 doi:10.1016/j.jhydrol.2014.02.012

West JW (2003) Effects of Heat-Stress on Production in Dairy Cattle Journal of Dairy Science 86:2131-2144 doi:http://dx.doi.org/10.3168/jds.S0022-0302(03)73803-X

\section{Figure captions}

Figure 1. Flood coverage and permanent surface water bodies in the Pampas. The location of the meteorological stations used in this study (stars) is colored according to the relative local flooding level; larger stars (Anguil, Pehuajó and Mar del Plata) correspond to the stations used in the extended temporal analysis (see text).

Figure 2. (A) Mean diurnal thermal range for the whole year (2000-2013) for the meteorological stations used in this study sorted by distance to Atlantic Ocean. (B) Mean seasonal thermal range (2000-2013). (C) Mean diurnal thermal range for the cold season (April to September) for periods of contrasting flooding (2000-2003, highly flooded and 
485

486

487

488

489

490

491

492

493

494

495

496

497

498

499

500

501

502

503

504

505

506

2004-2009, non-flooded). Black and gray arrows indicate locations with high and intermediate fraction of flooded area, respectively.

Figure 3. Mean diurnal thermal range for the cold season (April to September) based on remote sensing estimates of land surface temperature (LST- DTR) during: (A) a flooded period (2000-2003) and (B) a non-flooded period (2004-2009). (C) Detailed map of the most flooded area showing the distribution of flooded areas and permanent waters.

Figure 4. (A) Diurnal thermal range for (i) coastal (Mar del Plata), (ii) inland flooded (Pehuajó) and (iii) inland non-flooded (Anguil) locations for the 1971-2013 period, using a 365-day moving average. (B) Anomaly of diurnal thermal range for each month compared to the all-time monthly mean value at Pehuajó (circles), also shown using a twelve-month moving average (thick line). (C) Flooding in the Pehuajó area (10-km radius around the meteorological station) as estimated with remote sensing data for the 1980-2013 (log scale) or inferred from written records, with grey columns indicate periods of intense flooding.

Figure 5. Relationship between the mean monthly diurnal thermal range anomaly at Pehuajó meteorological station and the percentage of flooding in the surrounding territory (10-km radius).

Figure 6. Mean frost-free period estimated considering the dates of early-season and lateseason frost $\left(\mathrm{T}_{1.5 \mathrm{~m}}<2{ }^{\circ} \mathrm{C}\right.$, see text) and standard deviation, for the meteorological stations of Anguil (inland, non-flooded), Pehuajó (inland, flood-prone) and Mar del Plata (coastal, non-flooded) for flooded periods (grey bars; 1973, 1985-1988, 1997-2003, 2012) and nonflooded periods (black bars, rest of the years). The length of the mean frost-free period in days is indicated at the left of each bar. 
509 Table 1. Change in minimum, maximum, mean and range air temperature between flooded

510 (2000-2003) and non-flooded (2004-2009) periods, at 17 meteorological stations

511 distributed across the Pampas with different degrees of flooding (Fig. 1). Letters depict

512 significant differences $(\mathrm{p}<0.05)$ among levels of flooding based on an analysis of variance.

\begin{tabular}{|c|c|c|c|c|}
\hline & Degree of flooding & Nil-Low & Intermediate & Highly \\
\hline & Number of stations & 9 & 5 & 3 \\
\hline Flooded vs. non- & $\Delta \min .(\mathrm{K})$ & $0.3 \mathrm{a}$ & $0.65 \mathrm{ab}$ & $1.18 \mathrm{~b}$ \\
\hline flooded change & $\Delta \max .(\mathrm{K})$ & $-0.75 \mathrm{a}$ & $-1.01 \mathrm{a}$ & $-1.9 b$ \\
\hline & $\Delta$ mean $\mathrm{K}$ ) & -0.45 & -0.36 & -0.72 \\
\hline & $\Delta$ range $(\mathrm{K})$ & $-1.05 \mathrm{a}$ & $-1.68 b$ & $-3.08 c$ \\
\hline
\end{tabular}

514 Table 2. Theoretical diurnal heat exchange for five possible levels of the territory during 515 flooded vs. non-flooded periods..

\begin{tabular}{|c|c|c|c|c|c|c|c|}
\hline Water status class & 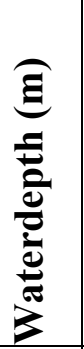 & 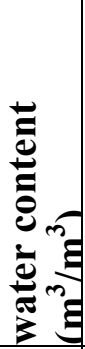 & 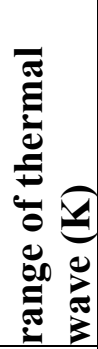 & 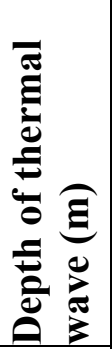 & 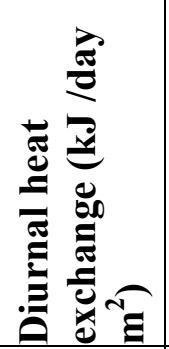 & 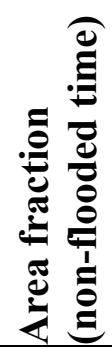 & 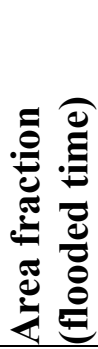 \\
\hline Permanent lagoons (well mixed column) & 2 & 1 & 1 & 2 & 8440 & 0.01 & 0.02 \\
\hline $\begin{array}{l}\text { Flooded area = shallow lagoon (stratified } \\
\text { column) }\end{array}$ & 0.5 & 1 & 3 & 0.5 & 6330 & 0 & 0.3 \\
\hline Saturated soil & 0 & 0.5 & 7 & 0.15 & 420 & 0 & 0.34 \\
\hline Field capacity soil & 0 & 0.2 & 9 & 0.15 & 540 & 0.495 & 0.34 \\
\hline
\end{tabular}




\begin{tabular}{|l|r|r|r|r|r|r|r|}
\hline Dry soil & 0 & 0.05 & 12 & 0.08 & 384 & 0.495 & 0 \\
\hline $\begin{array}{l}\text { Mean diurnal heat exchange of the } \\
\text { landscape }\left(\mathrm{kJ} /\left(\text { day } \mathrm{m}^{2}\right)\right.\end{array}$ & & & & & & & \\
\hline
\end{tabular}

516 